\section{Transplanting Specimen Palms: A Review of Common Practices and Research-based Information}

\author{
Dennis R. Pittenger ${ }^{1}$, \\ Donald R. Hodel ${ }^{2}$, and \\ A. James Downer ${ }^{3}$
}

ADDITIONAL INDEX WORDS. root growth, transpiration, leaf removal

SumMARY. Successful reestablishment of transplanted palms [members of the Arecaceae (Palmae)] depends on rapid regeneration of roots, avoiding injury and desiccation of the trees during transit and handling, and maintaining sufficient soil moisture around the root balls after transplanting. Since landscape contractors and nurserymen spend considerable resources and labor transplanting specimen palms, understanding the seasonality of palm root growth, how palm roots respond when trees are dug, and the effects of canopy manipulation during transplanting will enable them to adopt effective and rational transplanting practices. This manuscript provides a review of research findings that can be applied to maximize reestablishment of transplanted specimen palms.

$\mathrm{M}$ ature palms are the emblematic signature plant of Mediterranean and tropical landscapes. They are important and conspicuous elements in landscapes of Arizona, California, Florida, Hawaii, and other warm-climate areas. Large specimen palms of several genera are in great demand and command premium prices in California and other areas, costing $\$ 30$ to $\$ 400$ per 12 inches $(30.5 \mathrm{~cm})$ of trunk height, depending on the species, plus several hundred dollars each to transport and install

University of California Cooperative Extension.

${ }^{1}$ Botany and Plant Sciences Department, University of California-Riverside, Riverside, CA 92521.

${ }^{2} 4800$ Cesar Chavez Ave., Los Angeles, CA 91022.

${ }^{3} 669$ County Square Dr., \#100, Ventura, CA 93003
[W.D. Young \& Sons (Indio, Calif.) and Ellis Farms (Borrego Springs, Calif.); unpublished]. They are typically dug and removed from one landscape site or a nursery field, transported by truck, and replanted at another site to create an instant mature landscape.

Specimen palms are easy to transplant compared to large, broad-leaved, dicotyledonous and coniferous trees, which are characterized by large, multi-branched, woody root systems. A relatively small root ball is necessary when transplanting most palms because, as arborescent monocots, they have an adventitious root system composed of numerous, simple, fibrous primary roots that arise independently and periodically from the root initiation zone (RIZ) (Fig. 1) at the base of the trunk (Tomlinson, 1990). It is standard industry practice (SIP) for a root ball to extend $\leq 18$ inches $(\leq 45.7$ $\mathrm{cm}$ ) in radius from the trunk for transplanted palms up to $65 \mathrm{ft}(19.8 \mathrm{~m})$ tall with trunks 12 to 40 inches (30.5 to $101.6 \mathrm{~cm}$ ) in diameter. Although easy to transplant, many large specimen palms do not survive transplanting or they require an inordinate length of time to reestablish. Costly transplanting failure rates can be $30 \%$ in some installations (Meerow, 1997).

Successful reestablishment of transplanted palms depends on rapid regeneration of roots, avoiding injury and desiccation of the trees during transit and handling, and maintaining sufficient soil moisture around the root balls after transplanting. Considerable resources and labor are spent in following SIPs intended to optimize these factors, but there is a limited science basis to guide them.

\section{Time of year to transplant and seasonality of palm root growth}

The most common recommendation and SIP is to transplant palms during the warmer times of the year, ideally in late spring or early summer, because a long growing season is available for regeneration of the root system (Donselman, 1991; Hodel, 1995, 1996, 1997; Meerow, 1997). However, the landscape industries of southern California and other areas of the southwestern U.S. have been transplanting hardy palms, like mediterranean fan palm (Chamaerops humilis), canary island date palm (Phoenix canariensis), date palm (Phoenix dactylifera), queen palm (Syagrus romanzoffiana), windmill palm (Trachycarpusfortunei), california fan palm (Washingtonia filifera), and mexican fan palm (Washingtonia robusta), yearround with variable success to keep pace with year-round demand from urban development.

Broschat (1998) in Florida reported that palm root and shoot growth occurred throughout the year, but were greatest during the warmer times of the year when soil and air temperatures were highest. He suggested that palms could be successfully transplanted at any season in tropical areas and southern Florida because root and shoot growth in these warm humid climates were frequent and regular year-round. He suggested that winter planting was not advisable in cooler climates. However, published recommendations (Broschat and Meerow, 2000; Meerow and Broschat, 1992) advise the optimum time for planting palms

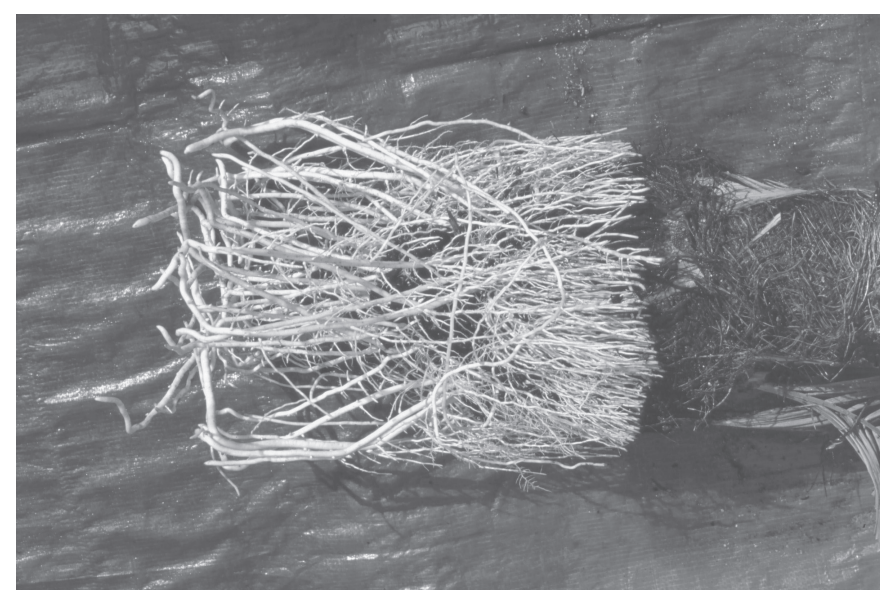

Fig. 1. The root initiation zone (RIZ) of a date palm (Phoenix dactylifera) offshoot. 
in warm humid climates is during the warm rainy season (June to October), because plant growth is highest and rainfall is normally sufficient to negate the need for supplemental irrigation.

In preliminary findings, Hodel et al. (1998) and Pittenger et al. (2000) reported that root growth of many palms generally tended to be highest during the warmer months from spring through fall in southern California. Recent findings by D.R. Hodel (unpublished) with field-grown specimens of 16 palm species generally support the above reports, and demonstrate that winters in California (and regions with similar Mediterranean climates) are sufficiently cool and long to reduce root growth in most species. Their data further show the window of opportunity for successful transplanting is usually smallest in the fall and winter and greatest in the late spring to early summer, but there were differences in this pattern in a few species. Based on their findings, transplanting palms in the fall and winter requires judicious attention to other factors that affect transplant success, such as digging and handling, planting depth, and irrigation. Late spring to early summer transplanting might be especially critical for rare and/or unusually valuable specimens or for any species that generate a preponderance of new roots in the summer. Thus, the literature indicates the best time to transplant palms in southern California and similar Mediterranean climates is the late spring to early summer (May to July) because transplanting at this time provides a long, warm period that promotes root growth and ensures the quickest and best establishment and survival.

\section{Palm root regeneration and root ball size}

Broschat and Meerow (2000) state that understanding how palm roots respond to digging is critical to successful transplanting. Until recently it was widely believed that palm roots cut during transplanting die and the tree must replace them with new primary roots from the RIZ, thus justifying the rationale for digging a minimal root ball. Indeed, in palmetto palm (Sabal palmetto) nearly all cut roots die back to the trunk, meaning when transplanted this palm has to generate an entirely new root system from the trunk to establish successfully and survive (Broschat and Donselman, 1984).
However, the literature shows that most palms are able to generate new root systems by the production of new roots from the RIZ and/or branching and regrowth of roots severed during transplanting.

Tomlinson (1961) stated that severed palm roots usually branch just behind the cut and continue growing. In Florida on field-grown palms, Broschat and Donselman (1984, 1990) found that the response of roots to cutting varies among species. In recently completed field research by D.R. Hodel (unpublished), 16 species showed varying degrees of branching and regeneration of severed roots with up to four branches per severed root. Branching and regeneration of severed roots was prolific in certain species, like canary island date palm, senegal date palm (Phoenix reclinata), queen palm, windmill palm, miniature chusan palm (Trachycarpuswagnerianus), and mexican fan palm, while it was minimal in other species, such as pindo palm (Butia capitata), mediterranean fan palm (Chamaeropshumilis), and scrub palmetto (Sabal etonia).

Digging the root ball is usually done by hand or a combination of mechanical digging with a backhoe and hand digging. However, there is no generally accepted recommendation for the optimal root ball size when transplanting large field-grown palms. Recommendations range from nearly no root ball to one as big as possible (Broschat and Donselman, 1987; Hodel, 1997; Meerow and Broshat, 1992). Some investigators have given much importance to the distribution of palm roots and their ability to branch and resume growth when determining the optimal root ball size. In sengal date palm, royal palm (Roystonea regia), queen palm, and mexican fan palm, Broschat and Donselman (1984, 1990) discovered some severed roots branched and regenerated from just behind the cut but, generally, the percentage of roots that branched and continued growing increased the farther the roots were cut from the trunk. In coconut palm (Cocos nucifera), about half of severed roots regenerated regardless of the distance from the trunk they were cut. Furthermore, they found senegal date palm, royal palm, and mexican fan palm produced high numbers of new roots from the base of the trunk, while coconut palm and queen palm generated relatively few. In the latter two species, however, the number of cut roots that regenerated was high, even surpassing the number of new roots originating from the trunk.

Based on their data, Broschat and Donselman $(1984,1990)$ recommended that the distance from the trunk at which $30 \%$ of the cut roots regenerated should determine the radius of the root ball. Thus, their recommended minimum root ball sizes, measured in the radius from the trunk, were 6 to 12 inches $(15.2$ to $30.5 \mathrm{~cm}$ ) for queen palm, 12 to 24 inches $(30.5$ to $61.0 \mathrm{~cm}$ ) for mexican fan palm, and at least 24 inches for senegal date palm and royal palm, because there was little regeneration of roots cut shorter than these lengths for the respective species. Root balls for these last three species are relatively large in order to encompass a sufficient percentage of roots that will branch and regenerate after being cut.

Hodel and Pittenger (2003) found similar results in date palm offshoots, where over two-thirds of new root growth was regeneration of roots severed during removal from the mother palm. The authors suspected that many of the roots reported as originating from the RIZ in earlier studies actually originated from severed roots.

Although specimen palms are mature enough to have a functioning RIZ, plant maturity can sometimes influence the functionality of the RIZ in younger palms and, thus, impact their ability to regenerate roots after transplanting. Broschat (1990) determined in pygmy date palm (Phoenix roebelenii) and parlor palm (Chamaedorea elegans) that root regeneration from the RIZ was dependent on the plant being mature enough for the trunk to have reached its maximum diameter and for the palm axis to have begun elongating vertically. In contrast, root regeneration and RIZ function were shown to be independent of these maturity indicators in date palm (Hodel and Pittenger, 2003), and overall root regeneration of juvenile plants was found to be abundant in transplanted date palm, canary island date palm, and queen palm (Hodel and Pittenger, 2003; Hodel et al., 2003).

In practice, regenerating a large number of roots quickly is most critical to successful transplanting of mature specimen palms, so the total number 
and density of new roots, rather than their origin or a tree's age, are the key factors in determining the root ball size. It is more important to take a root ball only large enough to assure that a relatively large number of new roots is regenerated from any source rather than simply one large enough to ensure that a maximum number of cut roots branch and continue growing. In support of this concept, an important finding of Broschat and Donselman (1984) and D.R. Hodel (unpublished) is that most of a mature palm's roots are found within 12 inches of the trunk.

Thus, another interpretation of the Broschat and Donselman data $(1984,1990)$ is that a root ball with a radius 6 inches out from the trunk would be sufficient for nearly all the species investigated because $\geq 50 \%$ of all new roots regenerated, regardless of origin, were found within that distance. More recent interpretations of these data by Meerow (1997), Meerow and Broschat (1992), and Broschat and Meerow (2000) placed less emphasis on the ability of severed roots to regenerate when determining root ball size. These sources recommend a root ball with a radius $\geq 8$ inches $(20.3$ $\mathrm{cm})$ larger than the trunk for trees up to $15 \mathrm{ft}(4.6 \mathrm{~m})$ tall and a radius $\geq 12$ inches larger than the trunk for larger or multi-stemmed trees. For palms where all the roots die back to the trunk, such as palmetto palm, they recommend digging a root ball only large enough to protect the RIZ, perhaps no more than a 6-inch radius from the trunk. New data from D.R. Hodel (unpublished data) suggest that a root ball 12 inches in radius from the trunk and 12 inches deep would be adequate for most palm species because this volume of soil typically includes $\geq 50 \%$ of the roots. A deeper root ball ( $\geq 24$ inches deep) might be advantageous for pindo palm, chinese fountain palm (Livistona chinensis) and queen palm to ensure $\geq 50 \%$ of the roots are captured. Also, a deeper root ball might aid in stabilizing and anchoring any transplanted palm in situations where wind or other factors could cause it to lean or be unstable.

\section{Root pruning and root- promoting substances}

Root-pruning certain palms 1 to 3 months prior to transplanting was suggested by Broschat and Donselman
(1984, 1987, 1990). The pruning purportedly stimulates a large number of new roots to grow from the base of the tree and a smaller root ball can be taken, but they provided no researchbased information to support the practice. Even if root pruning provides the positive benefits purported, there is serious concern with the practice in that any new roots from the trunk or regenerated from branching of roots cut during root pruning will be highly susceptible to damage during the digging, transporting, and replanting processes. Recent recommendations by Meerow (1997) and Broschat and Meerow (2000) seemed to place less emphasis on root pruning but state it might be useful in some cases.

While root-promoting substances are known to increase root regeneration in dicotyledonous trees, research on their use in palms indicates the application of auxin (indolebutyric acid) does not improve root initiation in a large number of species (Broschat, 1990). Thus, this practice is not recommended or widely followed.

\section{Planting depth}

Landscape designs sometimes specify planting groups of mature palms at a uniform height, but it is often impossible for landscape contractors to obtain multiple palms meeting the height requirement. Thus, a common practice is to plant trees deeper than they were originally grown in the nursery in order to meet the specification. There is very little research documenting the effects of planting depth on the survival and establishment of transplanted palms.

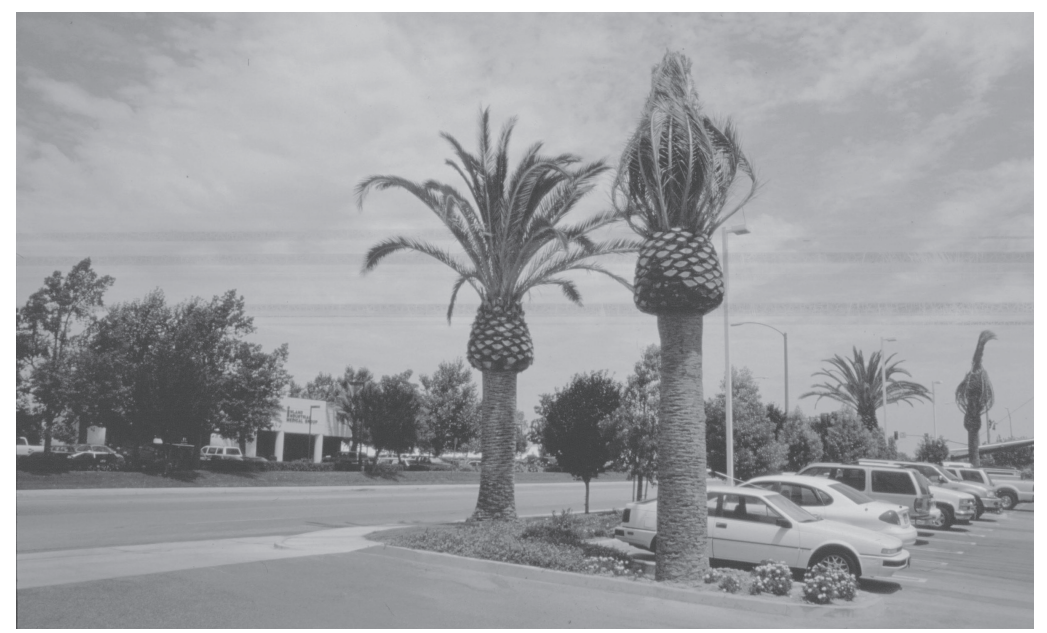

Fig. 2. Standard leaf tie-up and removal practice shown on recently transplanted specimen canary island date palm (Phoenix canariensis).
Root initials are often visible on the bottom 6 to 12 inches of palm trunks in the area of the RIZ, and visible or hidden initials may exist $3 \mathrm{ft}$ $(0.9 \mathrm{~m})$ or more higher on the trunk in some species (Broschat, 1995). Root initials above the RIZ do not usually develop into functioning roots unless they are in contact with a moist substrate (Tomlinson, 1990) or unless there is very high humidity maintained by frequent rainfall or irrigation. Broschat (1995) showed that planting mature pygmy date palms more than 5.9 inches $(15 \mathrm{~cm})$ above the top of the visible RIZ decreased tree survival and quality. These findings suggest that transplanting mature palms deeper than they were originally growing is not advisable, but it is impossible to make definitive recommendations on planting depth based on a study with one species.

In California, large specimens of mexican fan palm are sometimes transplanted 3 to $6 \mathrm{ft}(0.9$ to $1.8 \mathrm{~m})$ deeper than they were growing in their original location. However, the practice is controversial and not recommended because death and decline have been reported for many trees of this and other palm species planted in this manner.

\section{Leaf removal and leaf tie-up}

During the transplant operation, the SIP is to remove numerous functional leaves, up to $75 \%$ of the existing crown, and tie up the remaining ones, often for months after transplanting (Fig 2). These practices prevent damage to the crown and apical meristem during transport and handling, and 
they are purported by practitioners to reduce water loss of the dug tree, which improves the tree's chances of survival, and hasten its reestablishment. These practices greatly disfigure the crown of newly transplanted specimen palms, reduce their functional attributes, and detract from their aesthetic value for months or years, yet there is limited research documenting the benefits of either practice.

Removing at least half the leaves and tying up the remaining ones have long been common practices when severing offshoots of date palms from the mother tree and planting them out in the field. Growers state this practice reduces water loss and facilitates handling. Nixon and Carpenter (1978) and Zaid (1999), two of the best-known references on this subject, recommend this practice. Reuveni et al. (1972) reported that less severe leaf removal of offshoots did not improve rooting when planted in the traditional manner, but offshoots retaining all their leaves had higher rooting with overhead misting.

Broschat (1991) and Costonis (1995) showed that for species like the palmetto palm, which must generate an entirely new root system when transplanted, complete leaf removal greatly improved survival rates because the practice reduced transpirational water loss. Conversely, Broschat (1994) showed that transplanted pygmy date palms had higher new root and shoot growth and survival rates when most or all leaves were left on the palm, provided there was sufficient irrigation. He predicted that most other species of palms would probably respond similarly to the pygmy date palm, and he recommended that leaves should be untied after transplanting because research had shown no benefit from the practice in humid climates. He further suggested leaf tie-up promotes disease by decreasing air flow through the canopy, but in arid climates there might be some benefit from keeping the leaves tied up for several weeks to reduce transpirational water loss. Recently, Broschat and Meerow (2000) recommended that one-half to twothirds of the leaves should be removed to minimize transpirational water loss in large, specimen-sized, field-grown palms but they did not cite supporting data.

In a recent study with juvenile canary island date palms and queen palms, Hodel et al. (2003) found no effect on tree survival after transplanting from various combinations of amounts of leaf removal with and without leaf tie-up. They failed to document any reduction in transpiration or increase in leaf water potential in either species from any treatment combination either immediately after transplanting or during the following 6 months. In addition, no treatment resulted in greater numbers of new leaves or mass of new roots produced in either species. Based on their work with juvenile palms and earlier findings of Broschat (1994) and Reuveni et al. (1972), Hodel et al. (2003) concluded that for most palms it is possible that little or nothing is gained from leaf removal and/or tie-up during transplanting if the root ball and backfill are kept moist. They further stated there is doubt that these SIPs are horticulturally sound except to facilitate moving and minimize damage to the crown and apical meristem during the transplanting procedure. In an ongoing follow-up study by these authors (D.R. Pittenger, unpublished), it appears that leaf removal and tie-up do not improve survival or reestablishment of california fan palms having 6 to $10 \mathrm{ft}$ ( 1.8 to $3.0 \mathrm{~m}$ ) of trunk, which supports the authors' published findings for juvenile palms.

\section{Irrigation}

The importance of keeping the root ball and backfill soil of a transplanted palm well watered was documented for pygmy date palm by Broschat (1994), who found that regular irrigation improved plant survival, plant quality, and root growth. In addition, he showed that placing sprinklers directly in the crowns (foliar misting) of transplanted palms was not as beneficial as applying water directly to the soil. Hodel et al. (2003) also suggested the value of keeping the root ball moist in their leaf removal and tie-up studies with canary island date palm and queen palm.

\section{Other practices}

There are other industry practices and factors sometimes associated with transplanting specimen palms that are discussed in the literature but for which there is no research-based information pertaining to their influence on or effectiveness in successful transplanting. These include:

- Use of bracing or other support to keep large trees upright during the first 6 to 12 months after transplanting in sites with frequent high winds (Broschat and Donselman, 1987).

- Monitoring and management of insect pests (weevils and borers) known to be attracted to stressed palms (Howard et al., 2001)

- Occurrence of root diseases when palm root balls are kept too wet, the site is poorly drained, or the palm is planted too deeply (Donselman, 1991).

- Site selection and soil amendment for palms (Broschat and Donselman, 1987; Harris et al., 1999).

\section{Conclusions}

Available research indicates that specimens of most palm species can be successfully transplanted with a root ball that is 12 inches in radius from the trunk and $\geq 12$ inches deep. The optimum time to transplant most specimen palms in southern California and areas with similar Mediterranean climates is the late spring to early summer (May to July), while in warm, humid, tropical areas such as southern Florida it is best to transplant palms in the rainy season (June to October). If post-planting irrigation is available, palms could be successfully transplanted at any season in warm, humid, tropical areas and southern Florida.

Root-pruning palms in advance of digging them for transplanting has no proven benefit, and the practice may result in serious damage to any newly developed primary or regenerated roots during the digging, transporting, and replanting processes. Similarly, the use of root-stimulating hormones is not beneficial in palms.

When transplanting a palm, research suggests it is important to set the tree so that its RIZ is at the same depth at which it was originally growing. Planting a palm with the RIZ buried $\geq 6$ inches below grade can cause tree decline or death, while planting a tree with the RIZ too high above grade can reduce root regeneration.

The SIP of removing a large number of leaves and tying up remaining ones during transplanting is probably useful in preventing damage to the crown and meristem during the operation, but there is little evidence the practice enhances survival and reestablishment of the tree. It may be best, both horticulturally and aesthetically, simply to remove only the older dead 
leaves, tie up the remaining crown until the palm is relocated in the new site, and then untie the crown immediately. Care should be taken to protect the root ball from physical damage and desiccation during the transplanting process, and the backfill around the new transplant should be kept uniformly moist until the plant is established.

\section{Literature cited}

Broschat, T.K. 1990. IBA, plant maturity, and regeneration of palm root systems. HortScience 25:232.

Broschat, T.K. 1991. Effects ofleaf removal on survival of transplanted Sabal palms. J. Arboricult. 17:32-33.

Broschat, T.K. 1994. Effects of leaf removal, leaf tying, and overhead irrigation on transplanted pygmy date palms. J. Arboricult. 20:210-213.

Broschat, T.K. 1995. Planting depth affects survival, root growth, and nutrient content of transplanted pygmy date palms. HortScience 30:1031-1032.

Broschat, T.K. 1998. Root and shoot growth patterns in four palm species and their relationships with air and soil temperatures. HortScience 33:995-998.

Broschat, T.K. and H.M. Donselman. 1984. Regrowth of severed palm roots. J. Arboricult. 10:238-240.

Broschat, T.K. and H.M. Donselman. 1987. Factors affecting palm transplanting success. Proc. Fla. State Hort. Soc. 100:396-397.

Broschat, T.K. and H. Donselman. 1990. Regeneration of severed roots in Washingtonia robusta and Phoenix reclinata. Principes 34(2):96-97.

Broschat, T.K. and A.W. Meerow. 2000. Ornamental palm horticulture. University Press of Florida, Gainesville.

Costonis, A.C. 1995. Factors affecting survival of transplanted Sabal palms. J. Arboricult. 21:98-102.

Donselman, H. M. 1991. Planting a palm tree.Coop. Ext. Serv. Fact Sheet ENH-46. Univ. of Florida Inst. of Food and Agr. Sci., Gainesville.

Harris, R.W., J.R. Clark, and N.P. Metheny. 1999. Arboriculture-Integrated management of landscape tress, shrubs, and vines. Prentice Hall, Upper Saddle River, N.J.

Hodel, D.R. 1995. An ounce of prevention. Amer. Nurserymen 182(4):68-75.

Hodel, D.R. 1996. Planting palms correctly for vigorous, attractive growth and fewer problems. Turf Tales 3(1):10-11.
Hodel, D.R. 1997. Planting palms. Grounds Maintenance 32:C10-12.

Hodel, D.R., A.J. Downer, and D.R. Pittenger. 1998. Palm root regeneration, $\mathrm{p}$. 46-50. In: D. Neeley and G.W. Watson (eds.). Proc. Intl. Wkshp. Tree Root Development in Urban Soils. The Landscape Below Ground, II. Intl. Soc. Arboricult., Champaign, Ill.

Hodel, D.R. and D.R. Pittenger. 2003. Studies on the establishment of date palm (Phoenix dactylifera 'Deglet Noor') offshoots. Part I: Observations on root development and leaf growth. Palms 47(4):191-200.

Hodel, D.R., D.R. Pittenger, and A.J. Downer. 2003. Effects of leaf removal and tie up on juvenile, transplanted Canary Island datepalms (Phoenix canariensis) and queen palms (Syagrus romanzoffiana). Palms 47(4):177-184.

Howard, F.W., D. Moore, R.M. GiblinDavis, and R.G. Abad. 2001. Insects on palms. CABI Publ., New York.

Meerow, A.W. 1997. Betrock's guide to landscape palms. Betrock Info. Serv., Hollywood, Fla.

Meerow, A.W. and T.K. Broschat. 1992. Transplanting palms. Coop. Ext. Serv. Circ. 1047. Univ. of Florida Inst. of Food and Agr. Sci., Gainesville.

Nixon, R.W. and J.B. Carpenter. 1978. Growing dates in the United States. U.S Dept. Agr. Info. Bul. 207, Washington, D.C.

Pittenger, D.R, A.J. Downer, and D.R. Hodel. 2000. Palm root regeneration and its significance in transplanting. In: T.G. Ranney (ed.). Metropolitan Tree Improvement Alliance (METRIA). Proc. 11th METRIA Conf. 20 Apr. 2004. <http://www.ces.ncsu.edu/fletcher/programs/nursery/metria/metriall $>$.

Reuveni, O., Y. Adato, and H. LilienKipnis. 1972. A study of new and rapid methods for the vegetative propagation of date palms. Proc. 49th Annu. Date Grower's Inst.:17-23. Indio, Calif.

Tomlinson, P.B. 1961. Palmae. Vol. II., p. 47-52 in: C.R. Metcalfe (ed.). Anatomy of the monocotyledons. Clarendon Press, Oxford, U.K.

Tomlinson, P.B. 1990. The structural biology of palms. Clarendon Press, Oxford, U.K.

Zaid,A. (ed.). 1999. Date palm cultivation. United Nations, FAO, Plant Production and Protection Paper 156. Rome.
A Review of the Effects of Transplant Timing on Landscape Establishment of Field-grown Deciduous Trees in Temperate Climates

\author{
Lisa E. Richardson-Calfee ${ }^{1}$ \\ and J. Roger Harris ${ }^{2}$
}

AdDitional INDEX words. fall, root growth, root regeneration, season, spring, summer

Summary. Prudent landscape professionals can enhance chances for successful establishment by timing tree transplant operations to coincide with ideal seasonal conditions. However, transplant timing is usually determined by economic factors, resulting in trees being transplanted at times that are unfavorable for their survival and growth. Knowledge of the effects of season of transplanting on the establishment of landscape trees can help assure the highest probability of success, especially since special post-transplant management may be required if trees are transplanted at unfavorable times. This manuscript reviews past and current research on the effects of transplant timing on landscape establishment of deciduous shade trees. Specific results are summarized from several key studies.

S eason of transplant affects posttransplant establishment in two general ways. First, season, or time of year, dictates specific plant growth stages (e.g., dormancy, shoot expansion, leaf drop) and consequently affects a variety of plant resources that influence the potential for quick post-transplant root system regeneration, the key to successful transplant establishment. For example, buds of

Department of Horticulture, Virginia Polytechnic Institute and State University, Blacksburg, VA 24061.

${ }^{1}$ Former Graduate Student; currently Assistant Professor of Biology, Queens College, Charlotte, N.C.

${ }^{2}$ Associate Professor; to whom reprint requests should be addressed. E-mail: rharris@vt.edu 